\title{
Psychological constructs in foreign policy prediction ${ }^{1}$
}

\author{
ANTHONY A. D'AMATO \\ Postdoctoral Fellow, Social Science Research Council, at the University of Michigan
}

This paper attempts a pre-factor analysis of a series of possible attitude-clusters ("constructs") and a suggested framework for linking them that may help in predicting foreign-policy decisional behavior or-what probably amounts to the same thing-in finding regularities in past decision-making behavior. In the literature the paper may be located as a possible middle course between the Scylla of quasi-psychological speculation on "realism," "power," "moralism," and "national self-interest" of the Morgenthau (1960)-Osgood (1953) school, and the Charybdis of the complex concern with personality, motivations, aspirations, and goals of the Snyder-Bruck-Sapin school (1962).

The relevant difficulty here with the Morgenthau school is not the frequently voiced charge of ambiguity or vagueness, but the fact that the terms used have some substantive "hard" content however illdefined. For instance, Morgenthau and Osgood "define" national interest in terms of "power," and state in normative-ambiguous terms that national decision-makers both act to maximize power and ought to act to

${ }^{1}$ I would like to thank J. David Singer, Robert C. North, Owen S. Stratton, and Alan Schechter for their detailed criticisms of an earlier draft, and Lincoln P. Bloomfield, Ithiel de Sola Pool, Fred C. Iklé, and Robert Jervis for their criticisms and encouragement. maximize power. However, the scheme immediately runs afoul of another fundamental distinction, that between "imperialist" and "status quo" nations; the latter apparently have little or no power-lust and ought not to have it (cf. Morgenthau, 1960, pp. 68-71). The basic problem is that nations may maximize different things at different times, and one value or goal may eclipse the other. All motives that are defined in terms of specific content are "impermeable" (Kelly, 1955) and thus either conflict with (and may be eclipsed by) other content-motives or, if they happen to be universally present, are useless in predicting differentiable international behavior.

The Snyder decision-making school appeared as an extreme reaction to the oversimplification of the Morgenthau school (Wolfers, 1959, p. 90), yet it immediately became entangled in unmanageable complexities. By attempting to trace down all the motivational, temperamental, and valueoriented antecedents to a given decision, and despite their avoidance of the immense problems that would have resulted from deeper findings of motivational-content inconsistency and cognitive dissonance, the authors ended with an apparently unreplicable scheme (see Singer, 1961, p. 84). Additionally, the earlier mistake of specificcontent motives was in fact repeated. For example, in analyzing the decision to resist 
aggression in Korea, Snyder and Paige concluded that "the risks and costs of this course of action were acceptable in terms of the values at stake" (Snyder, Bruck, and Sapin, 1962 , p. 247). But despite its vagueness, this is an extremely "concrete" (Allport, 1937, pp. 192-93) or "impermeable" (Kelly, 1955, pp. 79-81) motive in that it does not refer to constants in human behavior that could be transferred to other situations. Similar particularistic motivations, values, and goals are found throughout the Snyder study. The result is a proliferating intellectual ancestry of individual actions that reminds one of Mark Twain's "proof" that the human population has been decreasing with each generation because every man alive today had two parents, four grandparents, eight great-grandparents, and so on back to an immensely populous ancestry. It would appear that content motives, however numerous, would preclude replicability in other decisional situations, for each unique decision would seem to require at least one unique content motive or a unique configuration of the supersession of inconsistent motives.

The need both for replicability and parsimony (see Deutsch, Singer, and Smith, 1965) would appear to require a search for more abstract and transferable generalizations about decision-making behavior.

\section{Psychological Constructs}

This paper is accordingly concerned with identifying and structuring common personality regularities of predispositions to act toward the foreign policy environment. Terms which have been used to describe personal proclivities include "determining tendencies” (Allport, 1937, pp. 290-93), "attitudes" (e.g., Smith, 1956, p. 33), "traituniverses" (Stephenson, 1950), "world view" (Cohen, 1961, p. 287), "conceptual systems" (Harvey, Hunt, and Schroder, 1961), "an- schauungen" (Klein, 1951, pp. 332-33), "constructs" (Kelly, 1955), and, though it has connotative difficulties, "stereotypes" (Lippmann, 1922; Klineberg, 1954; Boulding, 1959).

The term "constructs" seems best for present purposes as it suggests an abstract structure for construing environment. Moreover, it emphasizes the hypothetical nature of the attitude-clusters and the fact that we are dealing with generalizations inferred from behavior (cf. MacCorquodale and Meehl, 1948). A person does not have a construct, strictly speaking, just as he does not have happiness, humor, anxiety, or any other "traits," "attitudes," or "factors" (Keller and Schoenfeld, 1950, p. 154). For these so-called intervening variables are incapable of direct empirical determination; rather, the most we can say is that a person demonstrates certain constructs by acting (or responding) in a certain way. Actual behavior is the independent variable from which we may infer constructs (Skinner, 1953, p. 203).

This is by no means a pessimistic conclusion even though many people have taken comfort in "explanations" of behavior in terms of happiness, love, hate, hunger, and thousands of other "attitudes." For these are false explanations, depending upon unverifiable intervening variables. Rather, the hope for a science of decision-making lies in the fact that humans demonstrate temporal constancy and strive for internal consistency in their reactions to their environment (Kelly, 1955; Brown, 1965, pp. 549-609; Sampson, 1964, pp. 236-98), ,2 and accordingly we may be on our way toward predicting behavior (thus "explaining” it as much as empirically possible [see

${ }^{2}$ Construct consistency may in part vary directly with the closedness of the cognitive system (Scott, 1965, p. 81). 
Blalock, 1961, p. 5]) if we identify constructs at the right level of abstraction.

Earlier convenient levels of abstraction in other fields include the "authoritarian" line of the J-type of Jaensch (1938), the F-scale of Adorno et al. (1950), and the "fielddependence" of Linton (1955). Scott (1965) has suggested some intriguing correlates of international images, and Robert C. North of Stanford University has been working on a domestic-international construct that involves the identification of the perceived "enemy" responsible for all social ills as either one's own country or (at the opposite polar extreme) foreign countries. The actual labels used to describe these and other constructs should not be invested with inherently explanatory powers, any more than early words invented to describe consistencies of behavior such as "happy" or "humorous" should be regarded as having any meaning apart from the syndromes they conveniently summarize. In other words, it does not matter whether we say a man has "X construct" or is "an authoritarian personality"; what is significant is that he has an attitudinal "correlation cluster" (Cattell, 1957, pp. 14-15) which includes traits such as submissiveness to authority, anti-intraception, and conformity to conventional values, and we can predict from the existence of these that he also will probably manifest, for example, a high degree of superstitiousness (see Adorno et al., 1950, pp. 744-83).

Constructs selected on a convenient level of abstraction may, in addition, be arranged orthogonally, which provides a much clearer total picture of their interrelationships. In Eysenck's pioneering system (1954, pp. 10812), the abscissa is used to denote the continuum of conservative-radical political beliefs, while the ordinate is used for the authoritarian-democratic construct. This makes it possible to describe Communists as located in the radical-authoritarian or radi- cal-democratic quadrants, and fascists in the conservative-authoritarian quadrant. Without such an arrangement, there would be a considerable muddling of the two constructs (as in fact happened in the early studies of the authoritarian personality which haphazardly equated authoritarianism with fascism; see Shils, 1954). A similar orthogonal approach, involving four dimensions instead of Eysenck's two, will be used in this paper.

The basic problem is to select the appropriate constructs. The number of possible constructs which may be inferred from human behavior is indeterminantly large, and even factor- and component-analytical techniques can only suggest a continuum of theoretically possible constructs in which inclusiveness is purchased at the cost of increasing vagueness. However, the task is simplified if we exclude all areas of human behavior that are irrelevant to decisionmaking in a particular field such as foreign policy. Numerous day-to-day attitude clusters (such as "humor," "sadness") would be of negligible relevance to foreign policymaking. In addition, foreign policy for the decision-maker is largely an abstract and verbal task. The decision-maker does not typically carry out his own policies; as a general rule, the closer the decision-maker is to the top the more remote he is from the operational environment (Frankel, 1959, p. 8).

Not only does decisional significance vary inversely with field exposure, but reinforcement typically occurs at the level of verbal acceptance by colleagues of a proponent's policy, rather than direct stimulus feedback from the environmental field in which the decision operates. Moreover, it is hard in foreign policy to reach a consensus that a given policy decision was a mistake; unlike the situation in all lower courts where an erroneous decision can be reversed on appeal, a foreign-policy decision is rarely süb- 
ject to authoritative revaluation. This increases the abstract and verbal nature of this field of endeavor.

For example, of the few foreign-policy decisions of major powers in recent years that have been generally criticized, how many were or are perceived by the decisionmakers to be erroneous? According to Sorensen (1965) and Schlesinger (1965), the Kennedy administration felt that the Bay of Pigs episode was based on false reports and faulty intelligence, and that the CIA operations had acquired a momentum that could not easily be checked. Moreover, even if the Bay of Pigs decision itself was an error, Kennedy and his advisers eventually felt it was worth its cost in its educational value, so that when the more momentous Cuban missile crisis of 1962 came along, the earlier logistic and intelligence errors of the Bay of Pigs were not repeated. Or, taking the Cuban missile crisis as an example of a Kennedy "victory," does it follow that Khrushchev perceived it as a Soviet "error"? Even this sort of formal logic does not apply in the area of foreign policy; Khrushchev and his advisers may also have felt that they "won" by the extraction of a pledge from Kennedy that the United States would not invade Cuba and perhaps by an undisclosed "deal" (on which we can only speculate) that Kennedy would reciprocate for the removal of the Cuban missiles by removing, six months later when the public would not associate it with the Cuban episode, the American offensive missiles in Turkey.

It may, of course, take a certain amount of high-powered rationalization to find something good in every foreign-policy decision, but it is safe to assume that decision-makers responsible for the policies will do just that (as all the various aspects of the Vietnam debate reveal). Thus rationalizations tend to reinforce initial perceptions. Moreover, “perceptual processes commonly are 'reinte- grative' in character" (Leeper and Madison, 1959 , p. 193); the prior perception will be reinforced in later stimulus situations that in part resemble the original one. Finally, feedback from the consensus of colleagues that large numbers of decisions were right and wise may tend to overshadow whatever criticisms come in with respect to particular decisions. A possible example is John Foster Dulles, who could ignore particular criticisms of his policies on the basis of his belief that in general he was doing the right thing and that few of his critics, unlike his close colleagues, could see the big picture (Hughes, 1963).

These considerations suggest that constructs relating to foreign policy may be more consistent, impervious to change, and parsimonious than constructs affecting daily behavior, which are often directly and physically contradicted by the hard facts of personal experience. The greater the distance from the operative field, the more convincing is the general conclusion of gestaltists that a person "lives only in terms of his dynamically-oriented perceptions, rather than in terms of the objective realities" (Leeper and Madison, 1959, p. 183). On the other hand, these considerations do not help us to identify particular constructs. The identification and definition of a construct is, in the first instance, intuitive, just as is any scientific theory. However, it does not arise in a vacuum, but rather out of a way in which a person observes and generalizes from events hitherto thought discrete. Once a construct, or theory, is articulated, it is then worked with and shaped and modified in light of further observations and criticisms of colleagues. This is the process by which some of the constructs in this paper, which have been invented and used by others, arose in the first instance, as well as the way I formulated and revised the constructs which may be original. 
Preliminary tests of the cohesiveness of the constructs on Wellesley students (who had no experience in foreign-policy decision-making except for game simulations) and by way of content analyses of a number of memoirs and autobiographies of twentieth-century statesmen resulted in some modifications of the construct components. The method used may be described as a rough pre-factor analysis, and the net result is simply a set of working hypotheses. The necessary next step would be to interview decision-makers along the lines of the questions suggested below, and to undertake content analyses (using several judges) of the memoirs and papers of statesmen. The application of factor and component analyses of such data would undoubtedly lead to further modifications of the definitions of the constructs suggested here, or even to the rejection of some of the suggested components.

\section{Four Foreign-Policy Constructs}

Four constructs relating to foreign policy decision-making, ordered dimensionally in a concrete-abstract continuum (Harvey, Hunt, and Schroder, 1961) starting with the most concrete, are:

(1) Systemic-Personalist: how the decision-maker perceives the mechanism of the environment of his decisions.

(2) Hawk-Dove: willingness to use power and force.

(3) Incremental-Avulsive: degree of change between present and former decisions.

(4) Flexible-Rigid: the degree of flexibility in the preceding constructs.

These constructs, to be described in detail below, are indicated in a polar form to avoid ambiguity ${ }^{3}$ and also because consis-

${ }^{3}$ As Cattell points out (1957, p. 87), the opposite to "north polar conditions" may in one tent negative answers to any given construct test are equally valid as indicators of the opposite polar construct.

\section{Systemic-Personalist}

This first construct is of a lower order of abstraction than the ones to follow, as it is a way of perceiving the field of foreign policy itself. It is peculiar to the field of foreign policy and probably of little use elsewhere. Yet it belongs to a class of constructs which describe in polar terms how particular experts view their operational environments. For example, lawyers may view law as a whole or any individual case as a purposive activity containing an internal morality that strives for self-consistency and justice (Fuller, 1964), or he may view it as a positivist set of commands to be interpreted solely according to the intention, whether good or bad, of the legislator (Hart, 1961; cf. Tomkins, 1963). There are "progressive" or "traditional" educators, "pure" and "practical" mathematicians, "fundamental" and "technical" stock market speculators, and macro- and micro-economists. Supreme Court justices might be typified, with respect to certain classes of constitutional cases, according to a construct of deference or nondeference to popularly-elected branches. $^{4}$

sense be "equatorial conditions" and in another "south polar conditions."

${ }^{4}$ Many jurimetric studies seem to adopt overly simplistic constructs such as "liberal-conservative" or "activist-nonactivist." Justice Frankfurter's career demonstrates the futility of these, as he was clearly a "liberal" in the 1930s and a "conservative" in the 1950 s (the country changed!); he demonstrated judicial restraint with respect to "political questions" but was an activist on the issue of police brutality. However, all these decisions of his may be explained on a deference-to-popularly-elected-branches construct. In the 1930s Frankfurter "liberally" approved Roosevelt's New Deal legislation just 
The construct "systemic" is used to refer to the perspective of the policy-maker which embraces the international system in its comprehensiveness and "exaggerates the impact of the system upon the national actors" (Singer, 1961, p. 80). It is the perspective of the outside observer looking in. It finds outside or "systemic" laws, such as balanceof-power, coalitions and equilibrium, community, and international law, impinging upon and largely explaining the operational codes of other national policy-makers. For example, the policy-maker in state A would tend to discount the personal vagaries, rumored motivations, and ambiguous ideologies of his counterpart in state $B$, and tend instead to predict the decisions of state $B$ in terms of the larger systemic principles.

The polar opposite construct, which for want of a better word might be called "personalist," is an inside-looking-outward perspective. The P-type policy-maker views himself and his counterparts in other countries as manifesting complete free will in deciding upon policy altematives independent of the theories of the international system, guided only by personal motivations such as lust for power or dedication to a political ideology.

This dichotomy has previously been viewed by Singer (1961) as two ways of studying international relations, but what he calls a "level-of-analysis" problem might just as well be viewed as a "level-of-perception" problem for the decision-makers themselves. The tremendous dichotomy in the literature between the systemic and the policy-oriented approaches must be symptomatic of more than mere scholarly convenience. If scholars

as he "conservatively" approved anti-Communist and immigration-control legislation in the 1940s and 1950s. He steered away from "political questions" involving voting and legislation, but did not hesitate to be active in nonlegislative and non-Presidential areas. and analysts view the international field from either of two perspectives, then decision-makers (who increasingly coopt scholars and analysts into their ranks) probably do also.

With this as an initial hypothesis, a study of decision-makers and many of their decisions has suggested the following additional characteristics of the polar viewpoints:

1. The S-type (systemic) readily perceives international law as an attribute of the international community, however primitive the community may be, and he perceives states as equal subjects of the law. He usually does not think of international law as something distinct from international politics; rather, his experience under the socializing aegis of international legal study communicates to him a particular kind of "consensus on the nature of the international system" (Coplin, 1965, p. 617). International law deals with states as equals; it defines their boundaries, the limits of their sovereignty, and their reciprocal rights and duties where jurisdictions overlap. Accordingly, the S-type is accustomed to think in terms of juridically equal states, to accept the idea of the General Assembly's onestate-one-vote, and to think of state interaction as if states were checkers on an international checkerboard (and not as vastly unequal chess pieces). On the other hand, the P-type (personalist) thinks of international law as just another tool to be manipulated, like "world opinion" or "morality," and his vision of international politics is not particularly shaped or distorted by the way in which he considers international law. $\mathrm{He}$ will tend to act first and let the legal adviser rationalize afterward. He generally has little need or patience for the notion of states as juridical equals, and would like to introduce weighted voting into the General Assembly.

1.1. Law in general, including interna- 
tional law, rests on a foundation of assumed and expected reciprocity. The S-type will readily perceive the reciprocity of events and the precedent value of conduct that gives rise to international standards (cf. Fisher, 1961). For example, Adlai Stevenson called the Connally amendment a "legal boomerang." He stated that "we can refuse to be a defendant in the World Court, to be sure; but by that same token, because of the rule of reciprocity, we can hardly expect to be a plaintiff either" (1961, p. 962). At another time, Stevenson took an antiPortugese position on the Angola question following his pro-Portugese position on the Goa issue, asking rhetorically (to Portugal's dismay): "Can exceptions be made from standards of conduct we have all accepted without risking that they will be followed in other cases?" (1962, p. 389). Cordell Hull's memoirs show on nearly every page an obsessive concern for precedents and prior decisions of other secretaries of state (1948). In contrast, the P-type will think of the special circumstances of each decision and have a deep distrust of analogies and theorizing. ${ }^{5}$ This appears to have been the kind of thinking behind India's decision to take over Goa in 1961 or the United States' decision to intervene militarily in the Dominican Republic in 1965. There were perhaps more instances in the Dulles period:

${ }^{5}$ It is important, particularly if one were to undertake content analysis of Dulles' speeches, not to be misled by his recurrent "legalism" into thinking that his view was that of an international lawyer. As Hughes points out, Dulles was a courtroom lawyer: "As Secretary, he lived, acted, spoke, reacted, advanced, retreated, threatened, courted, summarized, analyzed, briefed, cross-examined, responded, appealed, objected, thrust, parried-like a lawyer. . . . He was, in effect, the prosecutor assigned to the historic labor of arraignment, condemnation, and punishment of the Soviet Union for crimes against freedom and peace" (1963, pp. 204-205). the stand with respect to Quemoy and Matsu, the nonadmission of China to the United Nations, the Suez decisions of $1956^{6}$ (see Finer, 1964, pp. 506-07), the "massive retaliation" threat, and the intervention in Lebanon in 1958.

1.2. Because he views nations as entities, the S-type is particularly troubled by divided nations or ambiguous boundaries. To President Kennedy, Vietnam was enigmatic, yet to the more personalist President Johnson there appears to be no particular difficulty in viewing the North-South struggle as a case of intemational aggression. Kennedy also had particular difficulties with Berlin; he was most afraid of a Soviet move there during the Cuban missile crisis (Schlesinger, 1965; Sorensen, 1965). The P-type, on the other hand, might be very patient with a divided Germany or with intervention in Vietnam. Intervention in smaller countries per se characterizes P-type decisions, as international legal concepts of sovereignty and territorial integrity do not appear as important restraints nor convey significant promise of future retaliation. The P-type will also agree to a "no sanctuary" policy in a limited war situation. When there are limits, he will emphasize functional rather than geographical considerations (see Snyder, 1961; Halperin, 1963).

1.3. The $S$-type will tend to be receptive to multilateral treaties ("Treaties must constitute the foundation on which any stable peace structure must rest"-Hull, 1948, p.

\footnotetext{
${ }^{6}$ Hughes points out that Dulles ignored the word "law" in his draft speech on the Suez crisis despite the appropriateness of the term and the fact that Eisenhower had just approved a different draft containing numerous references to international law, including the phrase, omitted by Dulles, "We cannot subscribe to one law for the weak, another law for the strong; one law for those opposing us, another for those allied with us. There can be only one law-or there shall be no peace" (1963, p. 219).
} 
229) whereas the P-type will tend to distrust multilateral treaties and conduct his foreign policy on the basis of bilateral treaties. It took an S-type Kennedy administration to push through the multilateral nuclear test ban treaty of 1963, whereas Secretary Dulles, a personalist, steadily undermined multilateral control of peaceful uses of atomic energy through the IAEA by a series of bilateral nuclear sharing and control agreements between the United States and other powers. However, if the subject matter of the treaty is a military alliance, the pattern is reversed. Here the P-type, having a general "we-they" view of the world (cf. Singer, 1961, p. 84), will prefer multilateral defense pacts (such as SEATO and CENTO under Dulles), whereas the S-type will want the flexibility of bilateral alliances that will make it possible to shift allies if that is necessary to achieve systemic equilibrium.

1.4. Finally, their view of states as part of an international system makes it easier for S-types to couple issues which are functionally unrelated (see Fisher, 1964, pp. 9798). Kennedy, as mentioned, feared that Russia would couple the Berlin issue with the Cuban missile issue to trade them off; perhaps Kennedy himself would have coupled the issues had the positions been reversed. But the P-type will tend to isolate issues; in this sense he may be less likely to escalate a local dispute into a world showdown, but the price paid may be an inability to solve particular disputes by trade-offs with other disputes. The generally personalist Johnson administration was able to order the bombing of Hanoi and of Soviet missile bases around that city while at the same time conducting normal relations with the Soviet Union in the economic and nonVietnamese political spheres.

2. Lacking the systemic determination of the S-type, the personalist decision-maker tends to impute a great deal of free-wheeling initiative and capacity for deception to his counterparts in other countries. $\mathrm{He}$ puts great emphasis in his speeches and writings on the trustworthiness of other statesmen. For example, James Byrnes in Speaking Frankly rarely refers to "Russia" but rather to individual Soviet officials (1947). Before World War I, Henry Stimson expressed his distrust of the Prussians due to their "martial swagger" (Stimson and Bundy, 1948, p. 83). $\mathrm{He}$ attributed his later success in achieving good relations with Nicaragua and the Philippines not to goal compatibility but because "trust begets trust" (pp. 114, 128). It may be postulated, subject to later empirical verification, that the P-type became a P-type because of considerable personal experience, whether in family life, school, or business, of broken promises, dishonesty, or blackmail. This experience may make him generally distrustful of advice (as Kennedy, an S-type, should have been with respect to his advisers on the Bay of Pigs episode). The P-type will delight in proving to his enemies that they do not deceive him; Dulles, for instance, frequently quoted Lenin's statement that "promises are like piecrusts, made to be broken" (Berding, 1965, p. 137). The P-type will have a "scrap-of-paper" attitude toward treaties, whereas the S-type, for a variety of reasons (see D'Amato, 1965) feels that treaties may last even when those who signed them start distrusting each other or are replaced by other officials. The P-type may himself be capable of considerable deception, whereas the S-type may be genuinely shocked when a great deception is practiced upon him. As an example of the latter, when President Kennedy became convinced that the Soviets had indeed installed offensive missiles in Cuba, he was privately furious: "If Khrushchev could pull this after all his protestations and denials, how could he ever be 
trusted on anything?" (Schlesinger, 1965, p. 802).

2.1. The S-type is not necessarily naive; rather, he is most likely to take at face value the assurances of foreign diplomats if their words coincide with the S-type's perception of what their systemically-determined foreign policy would be anyway. Given the relative ambiguity of diplomatic discourse, such perceptions might be reinforced in most cases. The P-type, on the other hand, feeling no need to evaluate messages against a theoretical backdrop, is more likely to be suspicious of all messages. In the summer and fall of 1962, Senator Kenneth Keating, possessed of no better information than the Kennedy administration, proclaimed loudly and often that the Soviets were installing dangerous missiles in Cuba; by October he was talking of offensive missile bases. To Keating, a P-type, this possibility was at least as likely as not, and Soviet messages to the contrary were just as likely to be lies as truthful. But to Kennedy, an S-type, Soviet assurances that Soviet technicians were not placing missiles in Cuba having an offensive capability coincided with his perception that it would make no systemic sense for Khrushchev, who could reach the United States with ICBMs anyway, to put offensive missiles within Castro's reach. Rather, Kennedy feared at the time a Soviet move in Berlin (Schlesinger, 1965, pp. 794-802). The subsequent discovery that Keating was right was indeed "incredible" (p. 801).

3. The S-type is decidedly less emotional on questions of ideology, morality, patriotism, and friendship than the P-type; the former maintains a Wilsonian impartiality and aloofness in his readiness to forsake old friends and engage in new coalitions to promote systemic stability. The S-type "keeps his cool"; in McLuhan's analysis, the Kennedy-Nixon television debates came out in Kennedy's favor because Kennedy was a "cool" personality operating in a "cool" medium, whereas Nixon's "hot" personality (a P-type in our terms) clashed with the "cool" medium of television (McLuhan, 1964, pp. 329-31). The P-type is quick to find friends and to uncover enemies, and he soon escalates this propensity into a view of the entire world from a "we-they" perspective. A rough content analysis of McGeorge Bundy's article, "Friends and Allies" (1962), reveals an overwhelming preponderance of human-oriented as opposed to theoretical words; he repeats words such as proud, brave, strength, character, interest, sympathy, harmony, desires, mature, gallant, insight, honor, generosity, habits, energies, convictions, conscience, integrity, and good men and women. Dulles often seemed to predicate this country's alliance policy on the sincerity and character of leaders of other nations. For instance, he found the ex-King of Cambodia to be "passionately patriotic," and was "much impressed" by Diem of Vietnam, whom he found to be "a true patriot, dedicated to independence and to the enjoyment by his people of political and religious freedoms" (1955a). He detested Communist China because its "regime has been consistently and viciously hostile to the United States" (1954). Like McGeorge Bundy, Dulles early concluded that "never in all our history was there a time when good friends and allies meant so much to us" (1953b). He attributed the friendship of allies to personal diplomacy, to cooperation "forged out of constant personal exchange of views with our friends" (1955b). Such preoccupation with friends and enemies made it easy for Dulles to be a coldwarrior, to state that "our proclaimed enemies" who are "plotting our destruction" control one-third of all the people of the world (1953a).

4. The usefulness of any construct depends on our being able in advance to indi- 
cate that a certain policy would be attractive to a specified type of construct; thus ultimately we are less interested in whether a given person is of a certain type than in whether a given policy can be characterized as belonging to a set which would be attractive to policy-makers having the relevant constructs.

Let us take two current examples: "fight nuclear proliferation" and "support the United Nations." While everyone professes to be against nuclear proliferation, S-types do more about it-place it higher on their priority lists-than do P-types. It is essentially an S-type issue, for the systematist greatly fears the systemic consequences of a number of nations having the ability to destroy others completely, and he is therefore likely to be deeply committed to restricting the nuclear club regardless of which nation is the next candidate to join. But the P-type is more concerned with precisely which nation is the $\mathrm{N}+1$ power; if friendly and responsible foreign statesmen develop their own nuclear capabilities, the world is not thereby made significantly more precarious. The problem to him is not the abstract spread of nuclear weapons, but rather keeping them out of the hands of enemies (and perhaps letting them go into the stockpile of allies).

Second, it is again the S-type who will actively support the United Nations as in part an end in itself. The P-type, on the contrary, will view the United Nations as just another instrument of foreign policy, to be made use of while it is around, but he will not worry too much if it leaves the scene. Dulles once wrote that "the United Nations, like the Sabbath, was made to serve man, not man to serve it" (1950, p. 57). Moreover, the S-type would support an international peacekeeping force since it would help to assert systemic values, while a P-type would be preoccupied with the question of exactly who would control and constitute the force and would probably oppose its establishment.

\section{Hawk-Dove}

The terms "hawk" and "dove" gained great popularity during the Cuban missile crisis of 1962 and have been endlessly repeated in connection with the Vietnamese war. They cause relatively little confusion in most instances, and indeed seem to be at least as descriptive of foreign policy attitudes as "liberal" and "conservative" are with respect to domestic (but not to foreign!) policies. The "hawks" with respect to Vietnam are those who would escalate the bombing of North Vietnam, even to saturation bombing (Madame Chiang Kaishek advocates atomic bombs). The "doves" advocate deescalation and emphasize the napalm-bomb killing of women and children. On the other hand, it would be the hawks in North Vietnam who would emphasize the napalm bombs as a way of rallying the population to greater efforts. In this sense Henry Stimson was a "hawk" in World War II in his advocacy of the release of photographs and motion pictures portraying the horror of battle and bringing the war closer to those at home (Stimson and Bundy, 1948, p. 498).

The hawk thus will tend to advocate the use of force in foreign policy, whereas the dove will be reluctant to use force. The H-type will tend not to be dissuaded by moral scruples in fighting a war; for example, Secretary Hull opposed the idea of sending food to Belgian children in World War II by arguing that it was the duty of the occupying nation to feed the conquered peoples and that "we could not afford to assist Hitler by relieving him of this obligation" (Hull, 1948, p. 1052). After the war the hawk will want to take drastic revenge. Again, Hull serves as an example in his ad- 
vocacy of summary treatment of the "world desperadoes." He stated that "the instigators of the war, German, Japanese, and Italian, should all be hanged" after a summary trial (pp. 1289-90).

The hawk-dove construct is simply a rewording of the toughminded-tenderminded construct (Eysenck, 1954; cf. Rokeach, 1956; Eysenck, 1956) that applies to any field of human activity. It would seem to be a reasonable hypothesis that daily character traits of toughmindedness would indicate a hawkish attitude in a person who happens to be a foreign policy decisionmaker. The following "opinion statements" were used in my classes at Wellesley College to test these constructs, and they may serve more clearly to define the constructs than any other kind of description:

("Agreement" or "strong agreement" with any of the following indicates H-type; "disagreement" or "strong disagreement" indicates D-type. $)^{?}$

The so-called underdog deserves little sympathy or help from successful people.

Allowing insults to our honor to go unpunished is dangerous since other nations will lose respect for us.

Our society is in decay; we should return to the fundamentals, to a more self-reliant way of life.

Insofar as India wanted to remove a Portugese enclave in her own territory, her action in 1961 with respect to Goa was justifiable.

We have overreacted against McCarthyism and are now in true danger of subversion from within.

During the Korean War, we should have bombed the air bases in Communist China, as General MacArthur advocated.

Force is often necessary to advance one's ideals.

Most of the students who protest the Vietnam

' Of course in the actual questionnaire the questions were not grouped together, but spread out among others testing for other constructs or included as throw-aways. war do so because they are too cowardly to fight.

The United States could use a tougher and more uncompromising president like De Gaulle.

The "limited war" in Vietnam is a no-win policy dreamed up by the civilian "strategists," and is against the sound advice of military leaders who want to increase the bombing of the North.

If one had to choose between freedom and order in a society, order is clearly preferable.

The Supreme Court has gone too far in protecting criminals.

Violent and sadistic crimes should be punished by flogging and long imprisonment at hard labor.

We ought seriously to consider the use of atomic bombs in North Vietnam.

No weakness or difficulty can hold us back if we have enough will power.

What youth today needs most is strict discipline.

The businessman makes a greater contribution to society than the professor.

People suffering from incurable diseases should have the choice of being put painlessly to death.

Compulsory military training is essential for the survival of this country.

It should be possible for any woman who wants to, to have easy and legal access to an abortionist.

Most religious people are hypocrites.

Those who make our foreign policy should not be sidetracked by moral principles, because the enemy does not obey the dictates of morality.

("Agreement" with the following indicates a D-type; disagreement an H-type.)

The death penalty is barbaric and should be abolished.

Blood sports, like fox hunting, are vicious and cruel and should be forbidden.

We should try to rehabilitate or cure criminals, not punish them.

One of the most criminal acts in world history was the dropping of atomic bombs on Hiroshima and Nagasaki.

Society must do everything it can to prevent suicides.

A "white lie" is still a lie.

It's better to be Red than dead. 


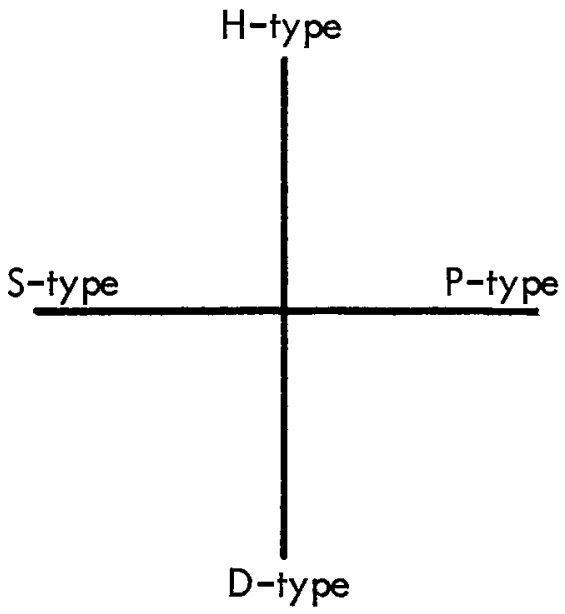

Frg. 1. Visualization of the systemic-personalist (S-D) and hawk-dove (H-D) constructs in relationship.

Thus far we have a construct scale as shown in Figure 1. It is easy to justify the orthogonal relationship. For instance, Stypes who are either doves or hawks will agree on the desirability of halting nuclear proliferation, but the hawk S-type in the upper left quadrant might advocate the bombing under UN auspices of the Chinese nuclear production facilities, whereas a dove S-type in the lower left quadrant would not go so far as to bomb mainland China. Of course, it may turn out later after more investigation that certain constructs cluster with others (perhaps H-types and P-types); if this is so, then more basic source-type constructs can be identified.

\section{Incremental-Avulsive}

Any of the preceding constructs may be held in varying degrees of personal commitment by a foreign policy decision-maker. Thus we need a construct that measures the degree to which a policy-maker will attempt to change existing policy to shape it more in the direction of his own constructs. The notion of incremental decision-making (see
Braybrooke and Lindblom, 1963; Cyert and March, 1963) is a useful concept for describing the propensity to stick to existing policy and change it as little as possible (cf. D'Amato, 1967, pp. 10-13). Cyert and March argue that decision-makers typically engage in an "approximate sequential consideration of alternatives," accepting the "first satisfactory alternative evoked" (1963, p. 113). The alternatives examined are usually marginal variations from the status quo. If existing policy must be changed, an incremental change-that is, a change in a relatively unimportant variable or a relatively unimportant change in an important variable (Braybrooke and Lindblom, 1963, p. 64) -is preferable to a large change.

For present purposes, it is unnecessary to go as far as the preceding authors in suggesting that the decisions are typically made incrementally, although it is immediately apparent that the State Department conducts well over 99 percent of its day-to-day business in that fashion. 8 Rather, we need only set up a construct describing the behavior of an individual engaged in decisionmaking that allows for a range between incrementalist and "avulsive" (a term invented to denote drastic change). If the individual typically behaves incrementally, then we label him an I-type; the A-type exhibits the tendency to come up with a decision that would produce a large change in existing policy.

${ }^{8}$ Two important exceptional cases of misreading of the opponent's $\mathrm{I}-\mathrm{A}$ construct are: (a) the US Department of State's "hard" position on article 19 of the UN Charter, based on the assumption, later proved false, that Russia would at the last minute avulsively back down; (b) Russia's decision to place missiles in Cuba in 1962, in part based on the assumption, later proved false, that the United States would react incrementally until the missiles were operational. 
The notion of incrementalism enshrines and normatizes the status quo. This procedure has historically been rationalized by conservative theorists such as Edmund Burke and Alexander Hamilton. It may be said in their defense that many advocates of "bright new ideas" for changing foreign policy do not sufficiently understand the wisdom of existing policy. This indeed appears to be the chief message of writers such as Morgenthau (1951) and Osgood (1953); their preoccupation with "realism" seems to be nothing more than a general feeling that "idealists" are often wrong. They argue, for instance, that Wilson's "moral crusade" to "make the world safe for democracy" in fact made matters much worse. Yet it does not appear that Morgenthau nor Osgood quarrel with the content of the ideals of the idealists they criticize; rather they seem to be taking issue with the limited vision of the idealists and their propensity to take avulsive action to implement their ideals. Thus the same arguments should apply to nonidealistic avulsive policy-makers, and indeed it would seem that all the criticisms of Wilson that Morgenthau mentions would apply equally well to Hitler, whose foreign policies turned out disastrously. The paranoid (see Tucker, 1965) and the idealist both want to change the world avulsively. On the other hand, sometimes the status quo if left alone can lead to ruin. Avulsive action was needed to stop Hitler in the late 1930s, and Morgenthau today appears to be calling for an avulsive (and not very "realistic") withdrawal from Vietnam (1965).

These indeterminacies demonstrate that "idealism," "realism," and even "paranoia" are specific-content constructs, and thus it makes no sense in general to attack or defend them. But the incremental-avulsive construct, in comparison, is abstract "source data" (Cattell, 1957) for the previously described constructs; it is helpful in predicting policies, regardless of whether the subject thinks he is acting to improve the world or to defend himself against his encroaching enemies. Since the I-A construct can indicate whether the decision-maker is prepared to insist upon implementation of his S-P or $\mathrm{H}-\mathrm{D}$ constructs, rather than going along with existing policy that is unsatisfactory to him, the I-A construct must be given a third dimension relative to the others.

The following "opinion statements" may help to further define the I-A construct:

(Agreement indicates I-type; disagreement A-type.)

It is natural to fear the future.

I would not do something dangerous for the thrill of it.

It is not wise to experiment too much with our foreign policy; there's a lot of wisdom in what we've been doing all along.

If a policy has worked well in the past, it is most likely the best policy.

If a change in policy becomes necessary, we should strive to make it as small as possible.

Young people sometimes get rebellious ideas, but as they grow up they ought to get over them and settle down.

(Agreement indicates A-type; disagreement I-type.)

Life becomes meaningful if you devote yourself to a cause.

All nuclear weapons ought to be turned over to an international agency under United Nations auspices.

The sooner we attack Communist China, the better off we'll be in the long run.

\section{Flexible-Rigid}

At the highest level of abstraction a construct is needed which measures the degree of variability of the other constructs along their continua. No one is likely to be a pure S-type or a pure P-type. Indeed, the decisions one makes and the responses one gives to questions will probably fall along the S-P continuum; an S-type may upon occasion make highly personalistic decisions. 
Nor would it be descriptive to take the average of all the person's decisions, for a single point along the continuum could summarize extreme variations or very close clusters. Clearly the standard deviation would be a useful descriptive compromise; it can be plotted on either side of the mean to indicate the normal variability range. ${ }^{9}$

The subject's flexibility might be defined in terms of the length of the standard deviation. But it would be more desirable to add a different test, treating flexibility as a separate construct. This is particularly important when the subject is new to the foreign-policy field or when for other reasons we do not have sufficient data on him. $\mathrm{He}$ may have been behaving incrementally, waiting for an important opportunity to take an avulsive step; for such a subject, it would be important to have an independent measure of capacity for avulsive behavior.

An independent flexibility-rigidity construct may derive its definition from the openminded-closeminded construct developed by Rokeach (1960) or from the more generalized cyclothymia-schizothymia construct of Cattell (1957, p. 90). Owing its intellectual ancestry to the studies of the authoritarian personality, the Rokeach construct contains many elements that are unrelated to foreign policy but may indicate a relevant correlative to it. Some "opinion survey" illustrations are:

(Agreement equals F-type; disagreement Rtype.)

Work is unrewarding if it requires too much attention to detail.

Many of my friends would probably be considered unconventional by other people.

${ }^{9}$ The formula for the standard deviation, given a set of numbers $x_{1}, x_{2}, \ldots x_{n}$ whose mean is $\bar{x}$ :

$$
\sqrt{\frac{\sum_{1=1}^{n}\left(x_{1}-\bar{x}\right)^{2}}{n}}
$$

We can improve ourselves by living for a while in a foreign country.

(Agreement equals R-type; disagreement Ftype.)

There is usually only one best way to solve most problems.

It is natural that women be restricted in ways in which men have more freedom.

"Op" and "pop" art have no place in the National Gallery in Washington, D.C.

Perfect balance is the essence of all good composition.

The United States and Communist China have nothing in common.

Barring emergencies I have a pretty good idea of what I'll be doing for the next ten years.

I often become so wrapped up in something $I$ am doing that $I$ find it difficult to turn $m y$ attention to other matters.

There will never be a lasting accommodation between Catholicism and Communism.

I have a work and study schedule which I follow carefully.

It is always important to be on time for appointments.

Most people don't know what's good for them.

Most college courses start out with a real promise of teaching theories which will explain large bodies of knowledge, but wind up criticizing the theories and leaving you with nothing.

One should be very careful about attire and manner of dress.

There's too much emphasis in college on theoretical topics and not enough on practical ones.

Generalizing from these statements, it may be said that a person is flexible or rigid depending on whether he can or cannot receive, evaluate, and act on relevant information unencumbered by his own constructs (cf. Rokeach, 1960, p. 57). Deutsch and Merritt (1965, p. 159) rightly stress the degree of receptivity to new messages and experience that characterizes flexibility, and whether inconsistencies in mental images "are treated as occasions for distortion and denial or as opportunities for learning." A flexible S-type, for example, might be intellectually convinced that the world is best 
explained in systemic terms, and he might act upon such beliefs most of the time. However, when faced with information that conflicts with his systemic construct, he will be flexible enough to switch to a personalist interpretation. For instance, if informed that Khrushchev might be putting offensive missiles in Cuba, the flexible S-type might react in saying that despite the senselessness in systemic terms of such an emplacement, Khrushchev might not be thinking in systemic terms (or he might simply be making a mistake) and thus one should not be caught wishfully thinking that the reports of the missiles are false.

An independent test of the F-R construct should then be compared to the standard deviation of all the other constructs. Perhaps an average of the two should be taken to determine the final length that indicates variability, although experience may dictate the usefulness of a weighted approach.

By constructing a three-dimensional graph of the S-P, H-D, and I-A scales, a cube would be generated having as its dimensions the standard deviations of the three scales. The volume of this cube would be a measure of the subject's flexibility. The number of unit cubes in this volume should be compared with the index of the subject's flexibility as independently measured by the preceding attitude tests, as previously suggested. ${ }^{10}$ Then, on the same model, each new alternative policy decision could be plotted according to the observer's evaluation of its $\mathrm{S}-\mathrm{P}$ and $\mathrm{H}-\mathrm{D}$ location and the degree to which it departs from previous policy (I-A). If this point in three-dimensional space falls within the cube generated by the subject's constructs, we may predict that he is capable of making such a decision

${ }^{10}$ The independent test of F-R could be pictured as the three-dimensional intersection of the tesseract F-R. and probably will. Something like this procedure is unconsciously performed by everyone who attempts to predict what a foreign policy-maker, whom he knows, might do with respect to a given policy alternative. The present suggestion merely puts it into a more sharply defined framework.

\section{Further Considerations}

The paradigm presented in this paper could be equally adaptable to a group of decision-makers or a country in the abstract; there is nothing intrinsically different between a mind and a group of minds in terms of decisional outputs. The only practical difference, a big one, is that it is easier to get non-foreign-policy decisional information about individual persons and also to interview them. Moreover, the personnel in a foreign-policy decision-making group often change, and this might lead to unmanageable flexibility. On the other hand, we should not assume $a$ priori that a person exhibits greater constancy and more strenuously avoids cognitive dissonance than a group. When in past centuries England acted as the balancer of power, she filled this role with a constancy that was independent of the personalities of the decisionmakers who came and went.

Another avenue for investigation might be the identification of other constructs, for the more dimensions that are used the more likely the vaguenesses of any given construct will be rendered less significant. However, some constructs are conceivable which are not at all useful. An example might be consistency-inconsistency. This is of course a valid construct: what one person sees as consistent another may see as inconsistent, despite all the strictures of logic (see Lecky, 1945). Some may see the United States' support of Franco as consistent with other aspects of its foreign policy, and others may 
see it as inconsistent. Yet the construct is not useful, for there is no objective test of consistency so that the observer might be able to plot a given policy alternative in such terms. The constructs suggested in this paper are the same for subject and observer alike, whereas consistency is dependent on a particular view of things that may not be shared by subject and observer, nor definable as among separate observers acting as judges.

Intelligence is another construct that would not be useful here. There is no way of equating intelligence with particular kinds of foreign policies. An intelligent decision-maker might be very flexible or he might be very rigid. So, too, an insane decision-maker might have the rigidity of paranoia or might exhibit purely random conduct which the observer interprets as high flexibility. Nor should this last possibility appear disconcerting, since the F-type is simply one who is ready to act on a basis other than that suggested by his constructs; random behavior is the most flexible of all. And indeed, in the foreign-policy field, such behavior might objectively be intelligent: compare the intelligent strategy of the "rationality of irrationality" (Schelling, 1960).

Finally, it is hoped that even in the absence of further empirical study and refinement of the constructs suggested in this paper, the theories presented may be used on a more impressionistic basis to help the organization of analyses of the history of foreign policy. Many articles and books have been written on the themes of idealism, realism, power, morality, isolationism, and internationalism; perhaps some of the constructs suggested in this paper can also be used as ordering concepts in this area of research.

\section{REFERENCES}

Adonno, T. W., et al. The Authoritarian Personality. New York: Harper, 1950.
Allport, Gordon W. Personality. New York: Henry Holt, 1937.

Berding, Andrew H. Dulles On Diplomacy. Princeton, N.J.: Van Nostrand, 1965.

Blalock, Hubert M. Causal Inferences in Nonexperimental Research. Chapel Hill, N.C.: University of North Carolina Press, 1961.

Boulding, KenNeth E. "National Images and International Systems," Journal of Conflict Resolution, 3, 2 (June 1959), 120-31.

Braybrooke, David, and C. E. Lindblom. A Strategy of Decision. New York: Free Press, 1963.

Brown, Roger. Social Psychology. New York: Free Press, 1965.

Bundy, McGeonge. "Friends and Allies," Foreign Affairs, 41 (1962), 1.

Byrnes, James F. Speaking Frankly. New York: Harper, 1947.

Cattell, Raymond B. Personality and Motivation Structure and Measurement. Yonkerson-Hudson, N.Y.: World Book, 1957.

Cohen, Yehudi A. Social Structure and Personality. New York: Holt, Rinehart and Winston, 1961.

Coplin, William D. "International Law and Assumptions About the State System," World Politics, 17 (1965), 615-34.

Cyert, Richard M., and J. G. March. A Behavioral Theory of the Firm. New Jersey: Prentice-Hall, 1963.

D'Amato, Anthony A. "The Neo-Positivist Concept of International Law," American Journal of International Law, 59 (1965), 32124.

. "Legal and Political Strategies of the South West Africa Litigation," Law in Transition Quarterly, 4 (1967), 8-43.

Deutsch, KarL W., and R. L. Merritt. "Effects of Events on National and International Images." In Herbert C. Kelman (ed.), International Behavior: A Social-Psychological Analysis. New York: Holt, Rinehart and Winston, 1965.

__ J. D. Singer, and K. Smith. "The Organizing Efficiency of Theories: The N/V Ratio as a Crude Rank Order Measure," American Behavioral Scientist, 9 (1965), 3033.

Dulles, John Foster. War or Peace. New York: Macmillan, 1950.

—. Radio and Television Address, US De- 
partment of State Bulletin, 28 (1953a), 21216.

- Press Conference Statement, US Department of State Bulletin, 29 (1953b), 811.

- Address to the Overseas Press Club, US Department of State Bulletin, 30 (1954), 540 .

- Radio and Television Address, US Department of State Bulletin, 32 (1955a), 45964.

- News Conference. US Department of State Bulletin, 32 (1955b), 677.

EYsEnck, H. J. The Psychology of Politics. London: Routledge and Kegan Paul, 1954.

- "The Psychology of Politics: A Reply," Psychological Bulletin, 53 (1956), 17782.

Finer, Herman. Dulles Over Suez. Chicago: Quadrangle Books, 1964.

Fisher, Roger. "Constructing Rules that Affect Governments." In D. G. Brennan (ed.), Arms Control, Disarmament and National Security. New York: Braziller, 1961.

- "Fractionating Conflict." In RogER Fisher (ed.), International Conflict and Behavioral Science. New York: Basic Books, 1964.

Fuller, Lon L. The Morality of Law. New Haven, Conn.: Yale University Press, 1964.

Frankel, J. "Towards a Decision-Making Model in Foreign Policy," Political Studies, 7 (1959), 1-11.

Halperin, MORTON H. Limited War in the Nuclear Age. New York: Wiley, 1963.

Hart, H. L. A. The Concept of Law. London: Oxford University Press, 1961.

Harvey, O. J., D. E. Hunt, and H. M. Schroder. Conceptual Systems and Personality Organization. New York: Wiley, 1963.

Hugnes, Emmet J. The Ordeal of Power. New York: Atheneum, 1963.

Hull, Cordell. Memoirs. New York: Macmillan, 1948.

JAENsch, E. R. Der Gegentypus. Leipzig: J. A. Barth, 1938.

Keller, Fred S., and W. J. Schoenfeld. Principles of Psychology. New York: Appleton-Century Crofts, 1950.

Kelly, George A. The Psychology of Personal Constructs. New York: W. W. Norton, 1955.

KLein, George S. "The Personal World Through Perception." In R. R. BLAKE and G. V. Ramsey (eds.), Perception: An Ap- proach to Personality. New York: Ronald Press, 1951.

Klineberg, Otro. The Human Dimension in International Relations. New York: Holt, Rinehart, and Winston, 1964.

Lecky, Prescott. Self-Consistency: A Theory of Personality. New York: Island Press, 1945.

LeEper, R. W., and P. MAdison. Toward Understanding Human Personalities. New York: Appleton-Century Crofts, 1959.

Linton, Harriet B. "Dependence on External Influence: Correlates in Perception, Attitude and Judgment." In M. T. MeDNIK and S. A. MEDNIK (eds.), Research in Personality. New York: Holt, Rinehart and Winston, 1963.

Lippmann, Walter. Public Opinion. New York: Harcourt, Brace and World, 1922.

MacCorquodale, K., and P. E. Meenl. "On a Distinction between Hypothetical Constructs and Intervening Variables," Psychological Review, 55 (1948), 95-107.

McLuhan, Marshall. Understanding Media. New York: McGraw-Hill, 1964.

Mongenthau, Hans J. In Defense of the $\mathrm{Na}$ tional Interest. New York: Knopf, 1951.

- Politics Among Nations. (3rd edn.) New York: Knopf, 1960.

-We Are Deluding Ourselves in Vietnam," New York Times Magazine, April 18, 1965.

Osgood, Robert E. Ideals and Self-Interest in America's Foreign Relations. Chicago: University of Chicago Press, 1953.

Rokeach, Mition, and Charles Hanley. "Eysenck's Tender-Mindedness Dimension: A Critique," Psychological Bulletin, 53 (1956), 169-76.

- The Open and Closed Mind. New York: Basic Books, 1960.

Sampson, Edward E. Approaches, Contexts and Problems of Social Psychology. New Jersey: Prentice-Hall, 1964.

Schelling, Thomas C. The Strategy of Conflict. Cambridge, Mass.: Harvard University Press, 1960.

Schlesinger, A. M., Jr. A Thousand Days. Boston: Houghton Mifflin, 1965.

ScotT, William A. "Psychological and Social Correlates of International Images." In HERBERT C. KELMAN (ed.), International Behavior: A Social-Psychological Analysis. New York: Holt, Rinehart and Winston, 1965. 
Shils, Edward A. "Authoritarianism: 'Right' and 'Left'." In R. Christie and M. JAHODA (eds.), Studies in the Scope and Method of "The Authoritarian Personality." Glencoe, Ill.: Free Press, 1954.

Singer, J. David. "The Level-of-Analysis Problem in International Relations," World Politics, 14 (1961), 77-92.

SkINNER, B. F. Science and Human Behavior. New York: Macmillan, 1953.

SMIth, M. Brewster, et al. Opinions and Personality. New York: Wiley, 1956.

SNyder, GlenN H. Deterrence and Defense: Toward a Theory of National Security. Princeton, N.J.: Princeton University Press, 1961.

SNYDER, Richard C., H. W. Bruck, and B. SAPIN. Foreign Policy Decision-Making. New York: Free Press, 1962.

Sorensen, Theodore C. Kennedy. New York: Harper and Row, 1965.

Stephenson, William. "A Statistical Ap- proach to Typology: The Study of TraitUniverses," Journal of Clinical Psychology, 6 (1950), 26-38.

Stevenson, Adlai E. Address at Fordham Law School, US Department of State Bulletin, 45 (1961), 962.

- United Nations Address. US Department of State Bulletin, 46 (1962), 389.

Stimson, Henry L., and McGeorge Bundy. On Active Service in Peace and War. New York: Harper, 1948.

Tomkins, Silvan. "Left and Right: A Basic Dimension of Ideology and Personality." In RoBert W. White (ed.), The Study of Lives. New York: Atherton, 1963.

TUCKer, RoBert C. “The Dictator and Totalitarianism," World Politics, 17 (1965), 555-83.

Wolfers, AnNold. "The Actors in International Politics." In W. T. R. Fox (ed.), Theoretical Aspects of International Relations. Notre Dame, Ind.: University of Notre Dame Press, 1959. 